Rev. Mus. Argentino Cienc. Nat., n.s.

11(1): 33-37, 2009

Buenos Aires, ISSN 1514-5158

\title{
Early Cretaceous Radiolarians from southernmost Patagonia, Argentina
}

\author{
Chris HOLLIS ${ }^{1}$, Sergio ARCHANGELSKY² \& Orlando CÁRDENAS ${ }^{2}$
}

\begin{abstract}
${ }^{1}$ GNS Science, PO Box 30-368, Lower Hutt 5040, New Zealand, C.Hollis@gns.cri.nz. ${ }^{2}$ Palaeobotany Division, Museo Argentino de Ciencias Naturales «Bernardino Rivadavia», Av. A. Gallardo 470, (1405),

Buenos Aires, Argentina, sarcang@fibertel.com.ar, palincard@yahoo.com.ar
\end{abstract}

\begin{abstract}
A radiolarian assemblage found in the lowermost strata of the Río Mayer Formation, as exposed at Estancia La Federica in Santa Cruz Province, Argentina, is described. The biostratigraphic markers of this assemblage indicate a late Berriasian-early Barremian age (early Early Cretaceous). The radiolarians have faunal affinities with early Cretaceous assemblages reported from offshore northwestern Australia and the western Pacific, northeast of New Zealand. A cool-water affinity is suggested for the Patagonian assemblage. Ten meters below the levels with radiolarians sediments bearing continental palynomorphs are found. They are referred to the Springhill Formation of Berriasian to Valanginian age.
\end{abstract}

Key words: Radiolarians, Rio Mayer Formation, late Berriasian-early Barremian, Santa Cruz, Argentina.

Resumen: Radiolarios del Cretácico Temprano de la Patagonia Austral, Argentina. Se presenta una asociación de radiolarios hallada en el sector inferior de la Formación Río Mayer expuesta en la Estancia La Federica en la provincia Santa Cruz, Argentina. Los elementos dignósticos de valor bioestratigráfico indican una edad Berriasiano tardío-Barremiano temprano (Cretácico Temprano inicial) para este conjunto. Los radiolarios tienen afinidades faunísticas con asociaciones halladas costa afuera del noroeste de Australia y en el Pacífico occidental, al noreste de Nueva Zelanda. Se sugiere que la asociación de radiolarios patagónicos se desarrolló en aguas frías. Diez metros por debajo de los niveles portadores de radiolarios se hallan sedimentos continentales portadores de palinomorfos que fueron referidos a la Formación Springhill de edad BerriasianoValanginiano.

Palabras clave: Radiolarios, Fm. Río Mayer, Berriasiano tardío-Barremiano temprano, Santa Cruz, Argentina.

\section{INTRODUCTION}

The Patagonian Austral Basin stretches over a large area offshore and onshore of Southern Argentina in Santa Cruz and Tierra del Fuego provinces (Fig. $1 \mathrm{~A}$ ). The area of study is located near the Lake San Martín where a Mesozoic sedimentary sequence (Riccardi, 1971; Arbe, 2002), begins with conglomerates (Arroyo de la Mina Formation), followed by the Springhill Formation that grades to the marine pelites of the Rio Mayer Formation (Fig. 1 B). These units correspond to the Río Mayer stratigraphic cycle, Springhill transgressive subcycle (ST 1 of Arbe, 2002). A marine fauna including the ammonites Aulacosphinctes, Virgatosphinctes and Aspidoceras occurs in the Lower Member of the Río Mayo Formation (Feruglio, 1936; Blasco et al., 1979; Kraemer \& Riccardi, 1997; Nullo et al., 1999; Arbe, 2002).

This section was made by a team working on the palynology and stratigraphy of the Springhill Formation in 2001, as part of the projects PICT
99-6044 of the SECyT and PIP 5093 of the CONICET (Argentina). Here the formation is mostly continental as shown with palynological data, but in the upper sector it grades to marine environments that are attributed to the basal part of the Río Mayer Formation. The age of the Springhill Formation varies according to its location in the basin, being older (Late Jurassic, Kimmeridgian to Tithonian) in the southernmost area of the basin (where it is found in the subsurface), but becoming younger (Early Cretaceous, Hauterivian to Aptian) towards the northernmost outcrops (Arbe, 1989; Kraemer \& Riccardi, 1997). It has an intermediate earliest Cretaceous age in the central region of the basin at Lago San Martín, where our section is located. Here the Springhill Formation was dated as Berriasian, based on Pelecypoda, Perisphinctidae and Belemnoidea (Riccardi, 1977), to Valanginian, based on foraminifera and ostracoda (Kielbowicz et al., 1984). This general heterochroneity is in line with the hypothesis of an early transgression that invaded South America 
from the south and slowly moved northward (Kraemer \& Riccardi, 1997).

Bertels (1989) made a biostratigraphic and palaeoenvironmental study of the foraminiferal assemblages in the Rio Mayer Formation at the 350 m thick Estancia La Federica section. The presence of both spumellarian and nassellarian radiolaria is mentioned, but without any further determination or illustration. A Hauterivian age was assigned to the lower third of the Rio Mayer Formation based on the presence of the benthonic foraminifera Citharina kochii (Roemer), Vaginulinopsis neopachynota Bartenstein \& Kaever, and Lagena hauteriviana cylincracea Bartenstein \& Brand. The upper two thirds of the section were dated in the Barremian, based on the presence of the foraminifera Verneuilinoides subfiliformis Berenstein, and Dorothia subtrochus (Berenstein), (Bertels, 1989). More recently, Riccardi and Medina (2002) mention the presence of abundant but crashed ammonoids Favrella americana (Favre) and Belemnopsis spp., in the lowermost part of the Rio Mayer Formation at Estancia La Federica section.

The section presented in Fig. 1 B was logged in the same area where Riccardi (1971) and Bertels (1989) worked. The purpose was to obtain palynological information from both continental and marine strata at the Springhill-Rio Mayer transition. In the course of palynological processing we were surprised to discover that well-preserved radiolarians were present in the marine part of the Rio Mayer Formation. This is the first time that several taxa of this group of siliceous-shelled marine plankton from this formation, and indeed for any Mesozoic unit in the Austral Basin, are determined and illustrated.

The material is lodged at the Paleobotanical Collection of the Buenos Aires Natural History Museum under the numbers BA Pb MEB stubs 341, 342, 343). Photographs were obtained with the use of a MEB Philips XL30 at the Buenos Aires Natural History Museum.

\section{RADIOLARIAN CONTENT}

Two samples were examined for radiolarians from the lower horizons of the Río Mayer Formation. A calcareous shale sample (5/03-B) contained only poorly preserved indeterminate radiolarians. However, a highly calcareous nodule (5/03-A), contained abundant radiolarians of early Cretaceous age. The assemblage is very similar to that described from ODP Site 765, offshore northwest Australia, by Baumgartner (1992), but unfortunately most of the species
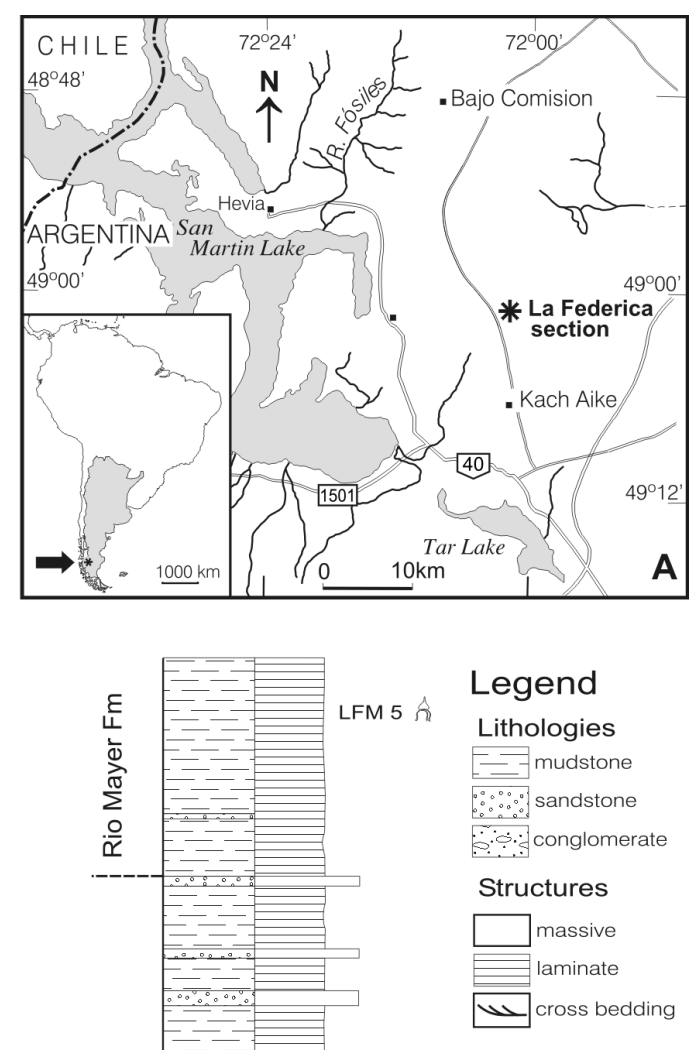

40) main road 1501 secondary road

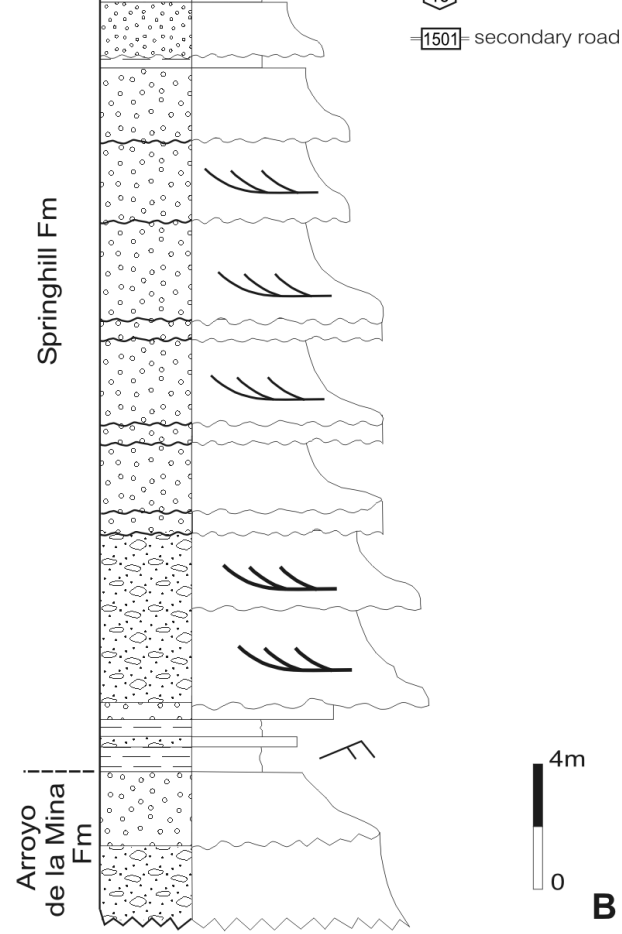

Fig. 1. A. Location map. B. Detail of La Federica section showing the horizon of the Río Mayer Fm. in which radiolarians were found (LFM 5). 

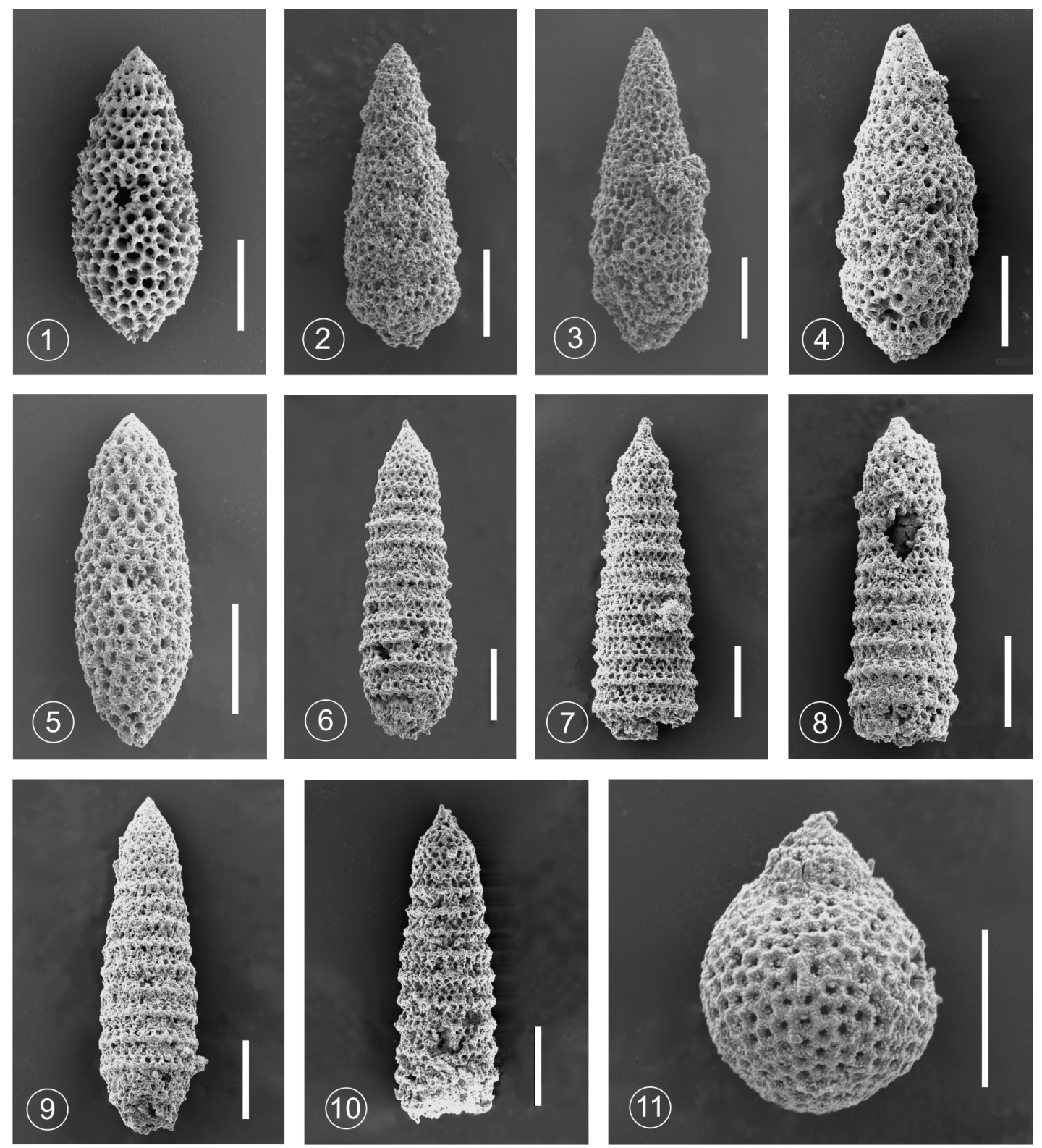

Fig. 2. 1. Eusyringium sp. A (MEB 341). 2,3,4. Eusyringium sp. B (MEB 343). 5. Pseudoeucyrtis sp. A (MEB 343). 6, 7. Parvicingula sp. A (MEB 343). 8, 9, 10. Parvicingula sp. D (MEB 343). 11. Sethocapsa orca Foreman (MEB 343). Bar $=100 \mu \mathrm{m}$.

have not been formally described. The biostratigraphic markers in this assemblage indicate a late Berriasian-early Barremian age (early Early Cretaceous). This age range is compatible with the Berriasian-Valanginian age of the underlying Springhill Formation in this area.

The key taxa in the assemblages include:

Eusyringium sp. A of Baumgartner (Tithonian to Barremian) (Fig. 2.1).
Eusyringium sp. B of Baumgartner (late Berriasian to Hauterivian) (Figs. 2.2, 2.3, 2.4).

Pseudoeucyrtis sp. A of Baumgartner (late Berriasian to early Barremian) (Fig. 2.5).

Parvicingula sp. A (late Berriasian to Valanginian) (Figs. 2.6, 2.7).

Parvicingula sp. D of Baumgartner (late Berriasian to early Barremian) (Figs. 2.8, $2.9,2.10)$. 
Sethocapsa orca Foreman (late Berriasian to early Aptian) (Fig. 2. 11).

These taxa indicate a late Berriasian-early Barremian age for the assemblage. A single specimen of the Jurassic genus Napora may be reworked or may represent an Early Cretaceous range extension for this genus (see Baumgartner et al. 1995). Other radiolarians of the Patagonian assemblage are referred to the genera Crucella sp., Obesacapsula? sp., Spongocapsula? sp. and Acaeniotyle? sp.

The Patagonian material has faunal affinities with early Cretaceous assemblages reported from offshore northwestern Australia (Baumgartner, 1992) and the western Pacific, northeast of New Zealand (Sutherland \& Hollis, 2001). The abundance of large multi-segmented nassellarians and the scarcity of warm-water radiolarians is taken as an indication of a cool-water affinity, which is consistent with this Patagonian assemblage.

\section{PALYNOLOGICAL CONTENT}

(Springhill Formation)

The first pelites that appear at the top of the Springhill Formation (Fig. 1 B) are placed approximately 10 meters below the bed where radiolarians are found. These pelites yielded a fairly rich palynological assemblage (presently under study) dominated by pollen of the conifers Callialasporites and Podocarpidites. Pollen of other conifers is less frequent, especially Classopollis and Araucariacites. The spore content is varied and several groups were identified: lycophytes (Densoirsporites), bryophytes (Foraminisporis, Aequitriradites, Staplinisporites), and different fern families that include Gleicheniaceae (Gleicheniidites, Ornamentifera), Schizaeaceae (Klukisporites, Trilites), Pteridaceae (Contignisporites) or Osmundaceae (Baculatisporites, Osmundacidites), among others. Fungal fragments belonging to the Microthyriaceae were also found. The assemblage is clearly continental and no record of dinoflagellates or other marine microorganisms were found at this level.

This palynological assemblage lacks two key araucariaceous genera, viz. Cyclusphaera and Balmeiopsis, that characterize younger (postValanginian) strata in the basin. It may be referred to the CCS or Contignisporites-Callialasporites-Staplinisporites biozone, dated in the Berriasian to Valanginian (Archangelsky et al., 1984). This zone was based on the assemblage found in the well YPF SC C-10, located to the SE of the Lago San Martín in Santa Cruz Province, and its pollen content was studied by Baldoni \& Archangelsky (1983).

\section{ACKNOWLEDGEMENTS}

We thank Lic. Gerardo Cladera for providing the unpublished section here illustrated as Fig. 1 B. Ms. Amalia González helped with the final drawing of the map and section.

\section{BIBLIOGRAPHY}

Arbe, H.A. 1989. Estratigrafía, discontinuidades y evolución sedimentaria del Cretácico de la Cuenca Austral, provincia de Santa Cruz. In: G. Chebli \& L. A. Spalletti (Eds.), Cuencas sedimentarias Argentinas, Instituto Superior de Correlación Geológica, Universidad Nacional de Tucumán, Serie de Correlación Geológica 6: 419-442.

- 2002. Análisis estratigráfico de la Cuenca Austral. En: M.J. Haller (Ed.), Geología y recursos naturales de Santa Cruz. Relatorio XV Congr. Geol. Argentino I-8:103-128.

Archangelsky, S., A. Baldoni, J.C. Gamerro \& J. Seiler. 1984. Palinología estratigráfica del Cretácico de Argentina Austral. III. Distribución de las especies y conclusions. Ameghiniana 21: 15-33.

Baldoni, A. \& S. Archangelsky. 1983. Palinología de la Formación Springhill (Cretácico Inferior), subsuelo de Argentina y Chile Austral. Rev. Española de Micropaleontología 15: 47-101.

Baumgartner, P.O. 1992. Lower Cretaceous radiolarian biostratigraphy and biogeography off northwestern Australian (ODP sites 765 and 766 and DSDP site 261), Argo abyssal plain and lower Exmouth Plateau. In: F.M. Gradstein, J .N. Ludden \& et al. (Eds.), Proceedings of the Ocean Drilling Program, Scientific Results, vol. 123 (College Station, TX, Ocean Drilling Program), pp. 299-342.

Baumgartner, P.O, L. O'Dogherty, S. Gorican, E. Urquhart, A. Pillevuit, \& P. De Wever. 1995. Middle Jurassic to Lower Cretaceous Radiolaria of Tethys: Occurrences, Systematics, Biochronology., v. 23: Lausanne, Switzerland, Memoires de Geologie (Lausanne), i-xxix, 1-1172 p.

Bertels, A. 1989. Paleoambientes de la Formación Río Mayer (Hauteriviano-Barremiano), Cuenca de Magallanes, República Argentina. In: L. Spalletti (Ed.), Contribuciones de los Simposios sobre Cretácico de América Latina. Parte A: Eventos y registros sedimentarios, pp. 45-56. Buenos Aires.

Blasco, G.B., F. Nullo \& C.A. Proserpio. 1979. Aspidoceras en Cuenca Austral, Lago Argentino, provincia de Santa Cruz. Rev. Asoc. Geológ. Argentina 34: 282-293.

Feruglio, E. 1936. Palaeontographia Patagonica. Mem. Ist. Geol. Padova 11/12: 1-384.

Kielbowicz, A.A., Ronchi, D.I. \& Stach, N.H. 1984. Foraminíferos y ostrácodos Valanginianos de la Formación Springhill, Patagonia Austral. Rev. Asoc. Geológ. Argentina 38: 313-339. Buenos Aires.

Kraemer, P.E. \& A.C. Riccardi. 1997. Estratigrafía de la región comprendida entre los lagos Argentino y 
Viedma, Santa Cruz. Rev. Asoc. Geológ. Argentina 52: 333-360.

Nullo, F.E., J.L. Panza \& G. Blasco. 1999. Jurásico y Cretácico de la Cuenca Austral. In: R. Caminos (Ed.), Geología Argentina 17: 528-535.

Riccardi, A.C. 1971. Estratigrafía en el Oriente de la Bahía de la Lancha, Lago San Martín, Santa Cruz, Argentina. Rev. Mus. La Plata n.s. 7, Geol. 61: 245318.

- 1977. Berriasian invertebrate fauna from the
Springhill Formation of Southern Patagonia. N. Jb. Geol. Paläont. Abh. 155:216-252.

Riccardi, A.C. \& Medina, F.A. 2002. The Bendauticeratinae and Cleoniceratinae (Ammonitida) from the Lower Albian of Patagonia. Revue Paléobiologie Genève, 21(1): 291-351.

Sutherland, R. \& C. Hollis 2001. Cretaceous demise of the Moa Plate and strike-slip motion at the Gondwana margin. Geology (Boulder), 29: 279282.

Recibido: 05-I-2009

Aceptado: 06-IV-2009 